\title{
TRADIÇÃO E MODERNIDADE NA OBRA DE LUCIAN BLAGA ${ }^{1}$
}

\author{
TRADITION AND MODERNITY \\ IN THE WORKS OF LUCIAN BLAGA \\ Rodica Grigore
}

Universidade Lucian Blaga de Sibiu

Sibiu, Romênia

Palavras-chave: Modernidade; tradição; poesia moderna; expressionismo.
Keywords: Modernity; tradition; modern poetry; secondary; Expressionism.

Cuvinte-cheie: Modernitate; tradi ie; poezie moder$\mathrm{n}$; secundar; expresionism.

\section{Resumo}

Lucian Blaga, poeta e filósofo, é, depois de Mihai Eminescu, o elo mais importante na cultura romena entre a tradição e a modernidade, entre uma "era heroica" de provação e sobrevivência e a nova época de consolidação. Blaga era um poeta de uma vocação dupla, um inovador e também um consolidador. Se os seus poemas de juventude expressam o espírito de uma modalidade transformada de expressionismo, os de maturidade ilustram uma atitude mais cética em relação à realidade. É claro, todos esses poemas iluminam e sấo iluminados por diferentes facetas da filosofia de Blaga; e ao mesmo tempo eles tornam problemáticos os aspectos conceituais de sua obra, submetendo-os a uma interrogação poética. Lucian Blaga foi o primeiro poeta romeno cuja obra estava sincronizada com formas artísticas europeias essenciais, e sua maior conquista talvez tenha sido a de adaptar o expressionismo para a poesia romena, mas sempre conseguindo manter uma direçáo original em sua obra, reavaliando os modelos e adaptando a "vontade de modernidade" para a cultura romena.

\section{Abstract}

Lucian Blaga, poet and philosopher is, after Mihai Eminescu, the most important link within Romanian culture between tradition and modernity, between a 'heroic age' of trial and survival and the new age of consolidation. Blaga was a poet of double vocation, an innovator and also a consolidator. While his early poems express the spirit of a transformed type of Expressionism, his

\section{Rezumat}

Lucian Blaga, poet și filosof reprezintă, după Mihai Eminescu, cel mai important punct de legătură din întreaga cultură românească între tradiţie și modernitate, între o epocă eroică a eforturilor de supravieţuire într-un context nu întotdeauna favorabil și noua eră a consolidărilor estetice. Blaga a fost de la bun început un scriitor al dublei vocaţii, deopotrivă inovator și continuator al

\footnotetext{
${ }^{1}$ Todas as citaçôes ou exemplos da poesia de Lucian Blaga foram retirados do At the Court of Yearning. Poems de Lucian Blaga. Traduçâo para o inglês e introdução de Andrei Codrescu, posfácio de Marcel Cornis-Pop, Columbus, Ohio State University Press, 1989.
} 
later ones illustrate a more skeptical attitude towards reality. Of course, all these poems illuminate and are illuminated by different sides of Blaga's philosophy; and at the same time they render the conceptual aspects of Blaga's work problematic, submitting them to a poetic interrogation. Lucian Blaga was the first Romanian poet whose work synchronized with some essential European artistic forms, his most important achievement being, perhaps, that of adapting Expressionism to Romanian poetry but also managing to keep an original course of his work, reappraising the models and relieving the "will to modernity" in terms specific to Romanian culture. tradiţiei, la care s-a raportat întotdeauna. Astfel, în vreme ce primele sale poeme marcau legătura autorului cu o inedită formulă expresionistă, volumele deplinei maturităţi ilustrează $\mathrm{o}$ atitudine mult mai sceptică în faţa realităţii. Desigur, poezia lui Blaga trebuie privită mereu prin prisma filosofiei sale, însă cititorul trebuie să ţină seama de faptul că lirica blagiană reprezintă, în sine, efortul de înţelegere și interpretare a ordinii universale. Blaga a fost cel dintâi poet român a cărui operă s-a sincronizat în mod deliberat cu o mișcare estetică europeană, însă meritul lui rămâne acela de a fi autohtonizat formula expresionistă și de a o fãcut realmente românească, prin recursul permanent la tradiţia specifică acestui spaţiu cultural, pusă, însă, în acord, cu toate provocările modernităţii.

\section{Tradição, modernidade e um novo tipo}

de imagem poética

Octavio Paz argumentou que os movimentos literários modernistas romperam "com a tradição imediata Simbolista e Naturalista, e que essa ruptura é uma continuação da tradição iniciada pelo Romantismo".* De um outro ponto de vista, R.-M. Albérès tratou da "aventura anti-intelectualista" da literatura moderna e definiu-a por uma clara dissociação entre experiência e intelecto (espírito).* Dentro deste contexto, a poesia espiritual e reflexiva de Lucian Blaga, bem como toda a sua obra, parece logo desde o início uma nota contrastante.

Um dos escritores romenos mais importantes do período entreguerras, Blaga (1895-1961) é bastante conhecido como poeta e filósofo, tradutor requintado, ensaísta sutil e dramaturgo notável. Se tivesse sido agraciado com o Prêmio Nobel de Literatura em 1956, quando parecia ter grande chance, seu trabalho teria sido estudado em todo o mundo da maneira que merece. No entanto, uma vez que a situação era muito complicada (especialmente por

* (PAZ, Octavio. Children of the Mire. Modern Poetry from Romanticism to the Avant-Garde. Trad. de Rachel Philips. Cambridge Massachusetts: Harvard University Press, 1974: 115.)

* (ALbérès, R.-M. L'Aventure intellectuelle $d u$ $X X^{e}$ siècle, 4. ed., Paris: Albin Michel, 1969: 87.) 
razóes políticas) e que o prêmio foi dado para Juan Ramón Jiménez, Blaga permaneceu relativamente desconhecido do leitor ocidental, sendo muitas vezes considerado um tipo de autor marginal ou periférico, com suas grandes realizaçóes ignoradas fora da Romênia. Acreditando que o mistério é uma parte integrante da vida humana, Blaga utilizou sua poesia para iluminar seu significado para os indivíduos e a sociedade, e seu sistema filosófico provou ser, pelo menos parcialmente, um tipo de panteísmo dominado pela busca por um princípio metafísico indescritível chamado de o "Grande Anônimo".

Quanto às grandes implicaçóes do seu sistema filosófico em questão, Lucian Blaga está em dívida com a Lebensphilosophie, em geral, e com a morfologia da cultura postulada por Riegl, Frobenius e Spengler, em particular, pois o escritor foi formado na escola alemã idealista-irracionalista na virada do século. No entanto, devese ressaltar que o pensador romeno tentou arduamente ir além de todos os seus modelos, e existem diferenças reais entre Blaga e seus antecessores, em relação aos quais o autor tinha um orgulho especial em indicá-los em várias ocasióes, observando que a filosofia que professavam tinha oferecido oportunidades quase sem precedentes. Sob o impacto da fonte que moldou seu pensamento, o conceito de cultura na obra de Blaga é diferente e oposto ao de civilização, livre de qualquer explicação causal ou determinação objetiva, flutuando como se estivesse miticamente em um mundo autossuficiente cujo escopo só pode ser descrito por meio de categorias abissais; daí os altos e baixos da filosofia da cultura de Blaga a despeito de sua grandiosidade lírica. Todo o seu arcabouço teórico, para o qual ele se esforçou admiravelmente por prover um estilo em termos arquimedianos - considerando estilo como uma característica definidora saliente da cultura humana, uma dimensão inerente a qualquer atividade humana criativa -, é um eco, em um outro nível, da ideia central que inspira a filosofia alemã já mencionada, de que a vida é imprevisível, indeterminada, o que equivale a dizer que a vida não pode ser traduzida em termos racionais. A principal realização de Blaga no campo da filosofia é representada por suas três trilogias: Trilogia do conhecimento (1943), Trilogia da cultura (1944) e Trilogia dos valores (1946).

Discutindo o lugar de Blaga no campo da cultura romena, mas também tendo em mente o contexto geral da literatura mundial, Marcel Cornis-Pop considera que esse autor "ocupa uma posi- 
ção singular na literatura romena moderna, comparável à de Eliot e Pound nos países de língua inglesa".* Na verdade, Blaga foi o primeiro poeta romeno cujo trabalho esteve sincronizado com algumas formas artísticas europeias essenciais. A sua realização mais importante talvez tenha sido a de "adaptar o Expressionismo à poesia romena"* conseguindo manter o curso original do seu trabalho, reavaliando os modelos e ressaltando a "vontade de modernidade" em termos específicos da cultura romena. Essa situação pode ser relacionada com o que Octavio Paz enfatizou em seu ensaio sobre as formas da poesia moderna: "Uma vez que um homem percebe que pertence a uma tradição", escreve o autor mexicano,

ele sabe implicitamente que é diferente daquela tradição; mais cedo ou mais tarde este conhecimento o leva a questionar, analisar e, por vezes, negar essa tradição. Nossa época é distinta de outras épocas e outras sociedades pela imagem que fazemos do tempo. Para nós, o tempo é a substância da história, o tempo se desdobra na história. O significado de "a tradiçấo moderna" emerge mais claramente: é uma expressão de nossa consciência histórica. ${ }^{*}$

O período entre as duas guerras mundiais foi a "idade de ouro do modernismo da Romênia":* Tudor Arghezi, Ion Barbu, Tristan Tzara, Eugen Ionescu, Mircea Eliade e E. M. Cioran são apenas alguns nomes que representam toda uma geração determinada a mudar alguma coisa na cultura romena. Alguns deles tornaram-se mais ou menos familiarizados com o mundo ocidental, especialmente depois de deixarem seu país de origem e estabelecerem-se principalmente na França. Mas deve-se destacar que, como Andrei Codrescu apontou, "as ideias do século XX desceram ao nosso pequeno país balcânico todas de uma vez e foram rapidamente absorvidas e transformadas".* Junto com alguns de seus contemporâneos, Blaga representa uma fase "construtivista" no modernismo romeno, principalmente porque, "ao reunir partes esparsas do Dadaísmo, do Futurismo e do Expressionismo e evitar o excesso da nova arte francesa (Surrealismo), o trabalho deles participou, mesmo que indiretamente, da reconstrução da arte europeia na era pós-Dadá".* Além disso, "o que distingue nossa modernidade da de outras geraçóes não é o nosso culto do novo e do surpreendente, por mais importante que seja, mas o fato de que ela é uma rejeiçáo, uma crítica do passado imediato, uma interrupçáo da continuidade. A arte moderna não é apenas o fruto de anos de críticas, é também a sua própria crítica”.*

*(CORNIS-POP, Marcel. Afterword: Existential Mystery and the Drama of Self-Expression in Lucian Blaga's Poetry. In: At the Court of Yearning. Poems by Lucian Blaga. Trad. e introd. de Andrei Codrescu. Columbus: Ohio State University Press: 189.)

* (Ibidem: 189.)

* (PAZ, op. cit.: 9.)

* (CODRESCU, Andrei. Lucian Blaga: An Introduction. In: At the Court of Yearning. Poems by Lucian Blaga, ed. cit.: $x i$.)

*(Ibidem: xii.)

* (CORNIS-POP, Marcel. A Rediscovered Circuit: The Romanian Literary Avant-Garde in Postwar Europe. The European Studies Journal, 3/1, 1986: 17-31.)

* (PAZ, op. cit.: 3.) 
Todavia, o tipo e a modalidade completamente novos de utilização da tradição poética por Blaga levantou enormes dificuldades ao trabalho da crítica. Em sua História da literatura romena, Eugen Lovinescu incluiu Blaga no "modernismo", embora seu estilo austero e "antilírico" contrastasse com o simbolismo musical de inspiração francesa da poesia romena tradicional da época. Em uma versão revisada da mesma história, publicada em 1937, Lovinescu realocou Blaga, situando-o entre os "tradicionalistas". Alguns anos mais tarde, George Călinescu também discorreu sobre Blaga como um tradicionalista em sua monumental História da literatura romena desde as suas origens até o presente, mas sua utilização do termo foi suficientemente flexível para cobrir o trabalho de um vanguardista ousado como Benjamin Fundoianu. $\mathrm{O}$ que ele argumentou sobre Fundoianu (ou seja, que seu tradicionalismo "representa uma forma de modernismo") aplica-se igualmente bem a Blaga. Como Fundoianu, Blaga empregou a paisagem rural conscientemente, rompendo as tradições imagéticas da qual ele fazia parte até então. $\mathrm{O}$ trabalho de Blaga questiona nossos preconceitos críticos, sugerindo que uma poesia mítica de orientação rural pode ser táo moderna e experimental quanto uma poesia relacionada com preocupaçóes urbanas.

Além dos aspectos mencionados anteriormente, Blaga pertence à família de criadores modernos destinados a ter uma "influência multifacetada predominante sobre a cultura a que pertencem”, considera Edgar Papu, sublinhando que esses tipos de estudiosos, “já anunciados por Nietzsche e que não podem estar ausentes de um lugar privilegiado, nem na história da poesia, nem na história do pensamento, têm aparecido em sucessão ordenada de Miguel de Unamuno a Jean-Paul Sartre. Sua polivalência fecunda não pode ser separada da unidade de sua própria personalidade, que, de todos os lados, irradia a mesma originalidade viva e a mesma mensagem".* Blaga marca um momento único na cultura romena: muito interessado em penetrar profundamente a essência de sua terra natal, e, ao mesmo tempo, ansioso por entrar em consonância com as ideias modernas de seu tempo, o poeta levou os recursos do espírito romeno para uma convergência culminante; ele criou seu próprio horizonte interior e o conectou com o perfil espiritual de seu povo, a fim de encontrar todos os reflexos específicos dos grandes horizontes deste circuito particular. Unamuno descobriu uma "essência" da Espanha e estabeleceu seu lugar no mundo, e 
Blaga fez exatamente o mesmo para a Romênia. Além disso, Blaga foi o primeiro a incluir a busca por traços últimos no registro filosófico, aplicando conceitos e categorias da filosofia da cultura especialmente para a "sub-história" romena, para os estratos sem registro da história conhecida visível. Ele derivou suas ideias de uma investigação das tradiçóes míticas da aldeia romena, resultando em uma filosofia intuitiva original da arte popular genuína e na determinação do horizonte mental de um espaço cultural específico. É por isso que, de suas três trilogias, A trilogia da cultura, a menos afetada pela metafísica agnóstica da filosofia de Blaga, parece ser a mais consistente. Talvez nela o espírito de Blaga (em geral subjetivo e metafísico) se aproxime da essência objetiva das coisas. Com intuição excepcionalmente sutil, ele aplica ao povo romeno uma filosofia original da cultura, como Unamuno fez para o povo espanhol, Okakura Kakuzo para os japoneses e Martinez Estrada para a terra Argentina e o tipo do "gaucho". Segundo Edgar Papu, Blaga certamente náo teria alcançado, "no plano do pensamento, tal agudeza intuitiva, se não tivesse sido, ao mesmo tempo, um poeta".* Foram feitas tentativas para estabelecer um paralelismo entre a sua filosofia e a sua poesia, ambas estando profundamente conectadas com um sentido de mistério. No entanto, a poesia é o domínio no qual o autor provou que sua adesão ao Expressionismo pode transformar um fenômeno de alguma forma "estrangeiro" em um fenômeno romeno, aplicando igualmente seus traços para a filosofia da cultura.

"O Impressionismo reduziu o homem à sua retina. Van Gogh mudou tudo isso fazendo as coisas participarem de sua vida interior. Ele fugiu da impressão provida pelo lado de fora, procurando ao invés a expressão investida da alma interior", escreveu Lucian Blaga em um ensaio sobre a arte, ${ }^{*}$ ao falar sobre a relação estabelecida entre o Impressionismo e o novo tipo de Expressionismo que ele mesmo professava. Portanto, podemos concordar com Marcel Cornis-Pop, que considerou que "a modernidade para Blaga foi duplamente constituída e manteve-se em tensão”. * O crítico levou em consideração as próprias palavras de Blaga, quando o poeta e filósofo afirmou em uma entrevista datada de 1926: "A poesia que melhor combina comigo é a ultramoderna, mas penso também que, em certos aspectos, ela é mais tradicional que o tradicionalismo comum, pois revive uma das conexóes com nosso substrato primitivo". A própria modernidade adquiriu definiçōes muito diferen- 
* (PAZ, op. cit.: 1.)

* (Ibidem: 59.)

* (CORNIS-POP, op. cit.: 190.)

* (Ibidem: 190.)

* (NEMOIANU, Virgil. The Current Relevance of Aesthetic Epistemology: The Case of Lucian Blaga. In: Don Quichotte, Summer 1985: 9-10.) tes durante as últimas décadas. No entanto, um dos críticos mais sutis que abordaram o tema, Octavio Paz, demonstrou de forma convincente que

a modernidade é uma tradição polêmica que substitui a tradição do momento, seja lá o que possa ser, mas um instante depois ainda dá seu lugar para outra tradição que, por sua vez, é uma manifestação momentânea de modernidade. A Modernidade nunca é em si; é sempre outra. O moderno é caracterizado náo só pela novidade, mas pela alteridade.*

Além disso, quando das primeiras décadas do século XX, “o que era novo não era tanto o que os poetas estavam especulando em prosa sobre a poesia, mas que essa especulação transbordou os limites das antigas poéticas, proclamando que a nova poesia também era uma nova forma de sentir e viver".* A conclusão em relação a Lucian Blaga, portanto, é indubitavelmente clara: "Depois de Mihai Eminescu, ele é o elo mais importante dentro da cultura romena entre tradição e modernidade, entre uma 'era heroica' de provação e sobrevivência e a era de consolidação. Blaga era um poeta de dupla vocação, um inovador (desregulador) e um consolidador".* Enquanto seus primeiros poemas expressam o espírito de um tipo transformador de Expressionismo, seus poemas posteriores ilustram uma atitude mais cética em relação à realidade. É claro que todos esses poemas iluminam e são iluminados por lados diferentes da filosofia de Blaga, e ao mesmo tempo "provêm os aspectos conceituais da obra problemática de Blaga, submetendo-os a um interrogatório poético”.* Quanto à relação entre a poesia e a filosofia de Blaga em questão, Virgil Nemoianu tentou esclarecer as coisas, afirmando que o trabalho deste criador é "duplamentecentrado": "Blaga começou a escrever poesia e filosofia quase ao mesmo tempo e continuou a expressar-se em ambos os modos ao longo de sua carreira ativa. [...] Um tipo curioso de autoespelhamento permeia a produção de estrutura gêmea de Blaga”.* Afinal de contas, essa atitude também é um aspecto que define a modernidade de Blaga.

Quanto à tendência moderna do Expressionismo em questão, deve-se mencionar que, na Romênia, Blaga foi o primeiro a mencionar os nomes de criadores tais como Däubler, Trakl ou Heym. Ele também utilizou suas leituras expressionísticas como um catalisador para seu próprio trabalho poético. Na verdade, seu primeiro volume, Poemas da luz (1919) contrasta as características conflitan- 
tes do "novo estilo", a fim de criar uma síntese original. O resultado é surpreendente, reunindo "vitalismo dionisíaco e espiritualização, euforia sensual e melancolia metafísica, interesse no substrato primitivo e transcendentalismo abstrato".* Marcel Cornis-Pop discute os detalhes deste novo estilo poético, considerando que "o expressionismo de Blaga foi no início abrangente e contraditório: um estilo poético mais que uma doutrina rígida, ele enfatizou a passagem da sensação para a abstração, do material para o espiritual, do fato à sua problematização - e vice-versa". * Como o próprio poeta explicou várias vezes e sugeriu no mesmo fragmento acima mencionado, ele se sentiu mais próximo em espírito de alguns dos grandes precursores do Expressionismo (Nietzsche, Strindberg e Van Gogh) do que de teóricos posteriores como Worringer. Mais do que isso - e complicando ainda mais todo o aspecto do seu específico e algo "inato" Expressionismo -, alguns dos primeiros poemas de Blaga são muitas vezes articulados em torno de imagens plásticas ou abstratas, trazendo à mente do leitor a obra de Brâncuşi.

\section{Filosofia, secundário, teoria e prática poética}

Como foi mencionado, a poesia de Blaga tem sido frequentemente analisada em relação com a sua própria filosofia. Em seus escritos filosóficos, o autor romeno afirmou que o mistério é o princípio por trás de toda a criação, e ele nomeou este princípio de o "Grande Anônimo", uma vez que não poderia ser determinado diretamente, mas apenas visto residualmente na natureza. Essa entidade também representou para Blaga a profunda alma do povo romeno, formando a consciência étnica coletiva que era a pedra angular de sua teoria do estilo. Abordando o problema, Virgil Nemoianu explica:

A filosofia de Blaga é um neoplatonismo no sentido inverso: a criação realmente tenta correr de volta para a sua fonte a fim de estar reunida com ela, mas o "Grande Anônimo", cheio de suspeitas sombrias e astuto ciúme, coloca obstáculos contra esse desejo e constrói freios na natureza contra o surgimento de Tipos ou Ideias realmente integradoras. Às vezes, de fato, ele parece mais interessado em frustrar do que em gerar.*

Embora alguns críticos tenham visto Blaga como um poeta da natureza preocupado apenas com o mundo físico e a experiência presente, outros explicam esta criação específica como a expressão de uma profunda melancolia e nostalgia por um paraíso perdido.
* (CORNIS-POP, op. cit.: 191.)

*(Ibidem: 191.)

(2)

* (NEMOIANU, Virgil apud Contemporary Literary Criticism, v. 75, ed. Thomas Votteler, Farmington Hills, Michigan: Gale Cengage, 1993: 57.) 
A maioria deles concorda, porém, que a ligação entre a poesia e a filosofia de Blaga revela as formas pelas quais a sua teoria da cultura é, em certa medida, inseparável das suas obras literárias.

Blaga obteve seu título de doutorado em filosofia em Viena com um tratado intitulado Kultur und Erkenntnis (Cultura e Conhecimento); esse foi o início de uma carreira filosófica distinta que se manteve fortemente em paralelo com a sua obra poética. Andrei Codrescu considera que "a filosofia de Blaga é 'poética', assim como sua poesia é 'filosófica'. As duas estão intimamente ligadas. Suas teorias sobre a cultura e a metáfora ecoam em seus poemas, e as descobertas inspiradas de sua poesia receberam uma análise rigorosa em seus ensaios".*

"O nosso dever, quando confrontados com um verdadeiro mistério", escreve Blaga, "não é explicá-lo, mas aprofundá-lo, transformá-lo em um grande mistério". Esse credo poderia ser discernido dentro de toda obra poética e filosófica de Blaga: em sua poesia. $\mathrm{O}$ mistério é abordado diretamente por meio da intuição e da música, bem como pela "invenção contínua de temas míticos”, assim como Codrescu argumenta em seu estudo. $\mathrm{O}$ "pensamento mítico", um princípio constantemente gerador na poesia de Blaga, também é uma ideia desenvolvida em ensaios como A filosofia do estilo e nas suas três trilogias publicadas entre 1943 e 1946. Portanto, "o mito e a metáfora são os fundamentos de sua visão de mundo".* No entanto, um dos críticos romenos de maior prestígio, George Călinescu, logo expressou as suas reservas quanto ao método de Blaga em questão, desaprovando-o de forma inequívoca e descrevendo o criador como um "verdadeiro místico" que aceitou o delírio como um instrumento de investigação e que ultrapassou os limites em busca de algumas novas expressóes literárias. Blaga, como ele próprio confessou em $A$ gênese da metáfora e o significado da cultura, tinha plena consciência de que sua tentativa de criar uma visão filosófica, e assim explicar o significado último do estilo e da cultura, do destino criativo do homem, não tinha conseguido encontrar uma linguagem que atendesse as suas necessidades científicas. A fim de expressar suas ideias, ele muitas vezes teve que recorrer a "imagens estranhas", míticas não filosóficas, isto é, ele foi além da filosofia propriamente dita e chegou ao reino obscuro, mas fascinante da mitosofia.

A teoria do estilo de Blaga foi grandemente influenciada pelos expoentes alemães da morfologia da cultura, especialmente 
por Leo Frobenius (um etnólogo e uma importante autoridade da arte pré-histórica) e Spengler. Um admirador precoce da obra $O$ declínio do Ocidente, Blaga descreveu Spengler como "um Copérnico da história" pela sua substituiçáo da morfologia pela cronologia na abordagem do desenvolvimento humano e por sua busca pelo "fenômeno arquetípico" por trás dos fatos históricos; ele colocou Spengler ao lado de Kant e Einstein como revolucionadores do pensamento. Levando em consideraçáo este aspecto, Keith Hitchins considerou que

Blaga tomou emprestado de Spengler a técnica do estudo comparativo das civilizaçóes e da antinomia entre cultura e civilização, mas achou a abordagem global de Spengler essencialmente deficiente: reduziram-se os fenômenos da cultura à forma, a despeito de ter abrangido muitos outros elementos e feito da intuiçáo do espaço o fator determinante do estilo, tratando-o como um ato criativo da sensibilidade consciente e não um produto das categorias inconscientes como Blaga propôs.*

Desse modo, em sua busca pela coordenada essencial do estilo cultural romeno, Blaga focou no mundo rural onde ele achava que os elementos constitutivos da espiritualidade romena poderiam ser encontrados. Foi por isso que ele concedeu à Ortodoxia um lugar orgânico na psique nacional, não estando fundamentalmente interessado em dogmas religiosos: por Ortodoxia ele quis dizer uma área étnico-geográfica capaz de distinguir seu povo dos católicos romanos ou dos protestantes europeus. O termo que utilizou deve ser entendido "em um sentido mais cultural que religioso", ${ }^{*}$ deixando claro que a originalidade do espírito romeno "não devia ser procurada em dogmas ortodoxos, mas nas derrogaçóes dele provocadas pelo 'espírito de heresia', que está no folclore semipagão preservado em lendas sagradas".* Blaga estava convencido de que por trás da máscara da Ortodoxia os romenos tinham preservado suas antigas crenças e costumes pré-cristãos, especialmente a sua forma de entender e sentir a existência, que, na opiniáo de Blaga voltou à era pagã dos trácios. O resultado foi que Blaga (ele próprio nasceu em uma pequena aldeia da Transilvânia e sempre foi fascinado por suas memórias de infância) pensou na aldeia tradicional romena como o modo de vida privilegiado e orgânico. Utilizando as antinomias de Spengler, ele definiu a existência criativa da aldeia como "cultura", enquanto a cidade incorporou totalmente a "civilizaçáo". A cidade moderna, portanto, deve ser entendida como um mundo
*(HITCHINS, Keith. 'Gandirea': Nationalism in Spiritual Guise. In: Social Change in Romania: Debate on Development in a European $\mathrm{Na}$ tion, edited by Kenneth Jowitt. University of California Press, 1978: 142.)

* (Ibidem: 144.)

* (Ibidem: 145.) 
* (NEMOIANU, Virgil. The Dialectics of Imperfection: Girard, Blaga, Serres. In: A Theory of the Secondary: Literature, Progress and Reaction, The Johns Hopkins University Press, 1989: 162.)

* (Ibidem: 164.)

*(Ibidem: 167.) mecanizado e burguês, cuja iminente desgraça Blaga, assim como muitos de seus contemporâneos (romenos ou europeus orientais, de Trakl a Eliot), previu e predisse. Daí a sua antinomia entre o mundo rural e a cidade, transformada mais tarde em uma teoria das culturas menores versus maiores, como expressou em seu estudo $A$ gênese da metáfora e o significado da cultura. "O exame cuidadoso e incessante de nossa cultura popular", escreve Blaga,

nos levou à conclusão revigorante sobre a existência de uma matriz estilística romena. Seus poderes latentes, de que temos um vislumbre, nos autorizam a afirmar que estamos possuídos de um elevado potencial cultural. Tudo o que podemos dizer sem sombra de dúvida é que somos os portadores afortunados de possibilidades excepcionais.

Colocar o trabalho de Blaga no contexto da filosofia ocidental é uma experiência interessante: ele parece ser um neospengleriano que absorveu as influências de Bergson, Dilthey e Nietzsche, ao reagir de alguma forma contra um pano de fundo platônico. "Em uma palavra, de um ponto de vista puramente ocidental, Blaga parece um continuador interessante, mas menor, das teorias de valor e vitalismo e da filosofia da cultura do século XIX”.* As dissociaçóes críticas e análises que Blaga faz acerca do freudismo, a revelação da unilateralidade e ineficiência da morfologia da cultura de Spengler, os insights profundos de Blaga lançando luz sobre as diferenças entre a condição do homem como ele realmente é e o modo como é apresentado pela espiritualidade cristã, sua crítica ao nietzschianismo cujos critérios descreveu como "uma careta histérica de um decadente", sua ênfase sobre as limitaçóes da teoria existencialista de Heidegger, são muitos os elementos individuais e importantes dignos de consideração especial. Blaga sustentou que o racionalismo e o empirismo não são nem um privilégio, nem um caminho promissor para alcançar o conhecimento ou satisfazer as aspiraçóes humanas, ao passo que uma integração entre conhecimento e mistério é muito mais apropriada. Como Virgil Nemoianu coloca, "isso significa uma atitude cooperadora do principal para o secundário".* O crítico argumenta que

para Blaga, a explicação das paralisias e relatividades epistemológicas é que o mistério (e poderíamos acrescentar, a secundaridade) é imposto pelos princípios estruturadores da própria realidade. [...] A vida humana não seria a mesma se desprovida de ausência ontológica. [...] A virada inesperada de Blaga para o relativismo moderno acrescenta uma dimensão mais construtiva e otimista desse relativismo.* 
Blaga é um criador do tipo problemático, com momentos de tensão e calma, impregnado de filosofia e fascinado por velhas imagens míticas ou ideias. Igualmente moderno e arcaico na expressão, um investigador de analogias entre o eu e o cosmos, apologista da luz do dia que entretanto saboreia as sombras do luar, o retrato deste escritor é cativante e difícil de traçar em poucas linhas. Não se pode penetrar a natureza íntima desse poeta, um dos maiores de toda a literatura romena, sem um sentimento de participação ativa, ainda que, teoricamente, náo se possa concordar totalmente com a sua filosofia. Além disso, se no caso de outros escritores o contacto com alguns dos seus trabalhos representativos pode ser suficiente, a criação de Blaga tem que ser lida e estudada na sua totalidade. As dificuldades encontradas pelo leitor desse trabalho lírico "são as dificuldades de qualquer mundo poético construído a partir de dentro".* No entanto, Andrei Codrescu sublinha claramente que, no caso de Blaga, "elas são agravadas por uma dependência quase total da nuance e do som para expressar 'o cósmico, o absoluto, o ilimitado", * como o próprio escritor expressou em sua Filosofia do estilo.

Estruturalmente, assim como demonstrou Constantin Ciopraga, um de seus intérpretes,

ele é um romântico de uma natureza dual, no início de um frenesi dionisíaco: "Nu-mi presimţi tu nebunia când auzi / cum murmură vieața-n mina / ca un izvor / năvalnic intr-o Peştera răsunătoare? I/ $\mathrm{Nu}$-mi presimţi văpaia când în braţe / îmi tremuri ca un picur / de rouă-mbrăţişat / de raze de Lumină?", "Nu-mi presimţi??" [Tu não pressentes minha loucura quando ouves / a vida murmurar em mim / como uma torrente impetuosa / em uma caverna que ressoa? // Tu náo pressentes minha chama quando em meus braços / tremes como uma gota / de orvalho envolta por raios de luz?, "Tu não pressentes?”], tocado ao mesmo tempo pela tristeza metafísica. ${ }^{*}$

Ao longo dos anos, o gráfico do frenesi vital apresenta uma queda; a tristeza, em ritmo de fluxo e refluxo, é mantida em vários matizes. Afinal, como Octavio Paz perfeitamente sublinhou, "as semelhanças entre o Romantismo e o século XX avant-garde são claras: ambos se rebelam contra a razão, suas construçôes e seus valores; ambos tentam a destruição da realidade visível, a fim de encontrar ou inventar uma outra, mágica, sobrenatural, além do real".* As ideias filosóficas de Mihai Eminescu estavam geralmente
* (CODRESCU, op. cit.: xvii.)

*(Ibidem: xvii.)

* (CIOPRAGA, Constantin Preface to Lucian Blaga, Poemele luminii / Poems of $\mathrm{Li}$ ght. Trad. Don Eulert, Stefan Avadanei e Mihail Bogdan, Buchaerest: Minerva, 1975: 39.)

*(PAZ, op. cit.: 102. ) 
* (CORNIS-POP, op. cit.: 193.)

* (CODRESCU, op. cit.: xvii.)

* (CORNIS-POP, op. cit.: 193.) implícitas em suas obras e seus escritos em prosa são de algum modo demonstraçóes de suas ideias poéticas. No entanto, a poesia de Blaga é essencialmente uma sequência de esforços rumo ao transcendente, um modo de expansão da grandeza milagrosa do cosmos, e do exílio interior, indicando uma personalidade dilemática. De seu primeiro volume, Poemas da luz (1919), seguido de Nos passos do profeta (1921), Na grande travessia (1924), Em louvor ao sono (1929), No divisor de águas (1933) e Nas cortes da saudade (1938), até a publicação póstuma de Poemas em 1962, seu sistema de experiências espirituais é acometido incessantemente por avanços e recuos, presunção e resignação, uma indulgência titânica autocentrada em um tipo particular de anonimato deliberado. Já em seus primeiros poemas, incluído no Poemas da luz, Blaga prova ter entendido algumas das tensóes presentes na postura expressionista, que mistura "entusiasmo cósmico e trágica histeria, fala perturbada e invenção verbal", como ele mesmo expressou. O mais importante é que todos estes aspectos foram exatamente aqueles considerados por Blaga os detalhes característicos do pensamento de Nietzsche. O Expressionismo queria afirmar a subjetividade, "mas por fim apagou-a pelo exagero (o "grito expressionista" de Worringer) e pela espiritualização excessiva.”* As duas alternativas oferecidas pelo Expressionismo (expansão cósmica e introversão, empatia e abstração) dissolveram o sujeito dentro do suprapessoal.

As imagens sensuais incluídas no seu primeiro volume (mas também no seguinte, Os passos do profeta) fizeram alguns críticos afirmarem que Blaga devia ser relacionado com o Impressionismo. $\mathrm{Na}$ verdade, todas essas imagens são "apenas expressóes exteriores de uma sensibilidade que procura tornar-se una com o cosmos e deixar a consciência para trás em uma total identificação com a natureza".* E mesmo se Blaga foi considerado "um imagista" por alguns principais críticos romenos (O próprio Eugen Lovinescu definiu-o como "um dos criadores mais originais das imagens sensoriais na literatura romena"), em uma leitura mais atenta, ele prova ser um excelente representante de um tipo específico de Expressionismo. Seu primeiro volume expressa as tensóes de uma alma poética sensível confrontada com um grande drama ontológico, o segundo já marca uma mudança efetiva de perspectiva e uma mudança de tom: "o fervor dionisíaco é substituído por uma interioridade ascética".* O que é expressionista em Blaga está igualmente relacionado com as práticas paroxísticas dos românticos: através do questionamento 
ininterrupto e do monólogo obsessivo, através do esforço para ver milagres, o poeta quer atingir a própria essência das coisas. E essa essência parece ser frequentemente encontrada nas zonas primárias, "ab originem", ou nas formas simples e elementares da vida contemporânea. Pelo "batismo na terra", ou seja, por um retorno aos significados primordiais, a revelaçáo não ocorre por meio da complexidade, mas da simplicidade. $\mathrm{O}$ resultado não é necessariamente uma completa iluminação, embora muitas vezes as linhas finais dos poemas de Blaga tenham um sentimento de resignação profunda. A ação aludida em um texto, intitulado "Compreendi o pecado que pesa sobre minha casa" / "Am înţeles păcatul ce apasă peste casa mea” ("Am înţeles păcatul ce apasă peste casa mea I ca un muşchi strămoşesc. I $O$, de ce am tălmăcit vremea şi zodiile I altfel decât baba ce-şi topeşte cânepa în baltă.?" ["Compreendi o pecado que pesa sobre a minha casa / como um musgo ancestral. / Oh, por que interpretei o tempo e os sinais / diferente da velhota que macera cânhamo na lagoa?”]), é colocada em oposição exata com os tormentos de consciência providos pela integração com o elementar ("De ce am râvnit altă menire / în lumea celor şapte zile / decât clopotarul ce petrece morţii la cer?" " "Por que cobicei um destino diferente / no mundo de sete dias / do tocador de sinos que celebra os mortos ao céu?"]). "É moderna a literatura moderna?", pergunta Octavio Paz, discutindo a relação complicada estabelecida entre esta e a produção dos séculos anteriores, bem como as características da "modernidade". Os Poemas de Blaga (e o supracitado é um exemplo) representam, a seu modo, uma resposta, embora sua modernidade tenha sido vista muitas vezes como ambígua, incorporando um conflito entre a poesia e o mundo moderno, que começou "com os pré-românticos e continua até hoje".*

Constantin Ciopraga chegou a comparar Lucian Blaga a Mihai Eminescu, o último importante poeta romântico da literatura mundial e a figura principal de toda a poesia romena. A atitude deles é diferente, mas não marca uma oposiçâo irreconciliável: "em face ao universo, Eminescu declama os monólogos do Olimpo, [...] enquanto Blaga, imbuído do novo mal du siècle, que é a inquietação moderna, está mais envolvido no presente".* Portanto, a palavra definidora para Blaga, neste papel específico de explorador do universo, é "saudade". Um detalhe importante é que um dos volumes essenciais de Blaga tem este conceito em seu próprio título: $N a s$ cortes da saudade (1938). Ele enfatiza uma alternativa que nos 
* (CORNIS-POP, op. cit.: 197.)

* (CODRESCU, op. cit.: xvii.)

* (Ibidem: 196.) leva além do drama do individualismo expressionista e apela para o abandono da subjetividade expressionista e um retorno ao anonimato mítico da aldeia.*

Adotando uma perspectiva diferente, Ştefan Augustin Doinaş comparou a semelhança entre a concepção da fala de Blaga e Hölderlin como estabelecida por Heidegger. O poeta alemão considerou a fala a mais inocente de todas as atividades, mas ao mesmo tempo a mais perigosa posse do homem, uma vez que por meio da fala é possível expressar absolutamente tudo. Nessas afirmaçôes heideggerianas, não é difícil identificar a tese poética contida implicitamente na poesia de Blaga. Blaga escreveu, em As faces de um século:

A linguagem humana, feita expressamente para apreender as coisas existentes externamente no espaço, não é capaz de identificar as nuances indefiníveis de consciência. Este processo pode ser conseguido apenas com a ajuda de uma intuição profunda que se libertou dos procedimentos matemáticos do intelecto, com suas categorias formadas por realidades espaciais.*

O silêncio torna-se um tema importante em seus poemas posteriores, como "Autorretrato" / "Autoportret": "Lucian Blaga e mut ca o lebădă. I In patria sa / zăpada fäpturii ţine loc de cuvânt. I Sufletul lui e în căutare, I în mută, seculară căutare, I de totdeauna, I până la cele din urmă hotare. I/ El caută apa din care bea curcubeul' ["Lucian Blaga está mudo como um cisne. / Em sua pátria / a neve do ser toma o lugar da palavra. / Sua alma está em busca, / em busca muda e secular, / desde sempre, / até os confins do mundo. // Ela busca a água bebida pelo arco-íris"]. Todavia, a idílica mudez de Blaga tem pouco em comum com o silêncio niilista de Beckett. Mesmo que isso contrarie o otimismo "expressionista" da poesia inicial de Blaga, sua exploração poética não tem fim. Pelo contrário, a busca órfica é levada além dos limites dados da realidade discursiva, provocando novos sentidos para fora das "runas" cósmicas.* O ensaísta romeno Nicolae Balotă foi o primeiro a apontar a ligação entre o tema do silêncio de Blaga e sua busca órfica. Além disso, em Euphorion (1969), ele percebeu que o silêncio e as palavras marcam duas regióes ontológicas diferentes: a primeira corresponde a um reino do náo criado, um espaço paradisíaco no qual o ser humano vive em um estado de graça inefável; a última significa a entrada do homem na temporalidade e na determinação, seu "cair em pecado", ou seja, a sujeição à sua própria condiçấo mortal. No poema "Segurando a mão do grande homem cego. 
Variante" / "De mână cu marele orb. Variantă" (incluído no volume $\mathrm{Na}$ Grande Travessia) podemos encontrar a chave (ou, pelo menos, uma chave) da atitude específica de Blaga. O grande homem cego é uma imagem do Criador cuja ordem cósmica o poeta elogia: " $\hat{l} l$ duc de mână prin păduri. I Prin ţară lăsăm în urma noastră ghicitori. / Din când în când ne odihnim în drum. / Din vânăta și mocirloasa iarbă / melci jilavi i se urcă-n barbă. // Zic: Tată, mersul sorilor e bun. / El tace-pentru că-i e frică de cuvinte. / El tace-fiindcă orice vorbă la el se schimbă-n faptă" ["Eu o conduzi pela mão através dos bosques. / Através do país deixamos em nosso rastro enigmas. / De vez em quando descansamos no caminho. / Das gramíneas do pântano lamacento / viscosos caracóis sobem em sua barba. // Digo: Pai, o caminho do sol é firme. / Ele cala, porque teme as palavras. / Ele cala, porque cada palavra que ele fala se transforma em ato"].

Pronunciando-se, a Palavra primeiro criou o mundo, obrigou-o a ser; mas obrigando-o a ser no tempo e no espaço, ela força sobre ele um status de limitação. A criação é um estado degradado do não criado: é a sua parte "decaída" quando vem sob a condição de evolução e morte que cada individualização implica. [...] Quando o Criador proferiu sua Palavra, ele nos condenou a ser, isto é, a sofrer e morrer.*

Ademais, a Palavra prova que a criação "continua a ser um imenso e inesgotável Mistério cujo sentido profundo e impenetrável não foi esclarecido de nenhum modo pela Palavra divina”.

O eu expressionista (como o "Pan" de Blaga) é progressivamente derrotado pelos sorrateiros sinais do tempo: "Acoperit de frunze veștede pe-o stâncă zace Pan. I E orbe și bătrân / Pleoapele-i sunt cremene, I zadarnic cearc-a mai clipi, / căci ochii-i s-au inchis ca melcii - peste iarnă. // Stropi calzi de roua-i cad pe buze: I unu, I doi, / trei. / Natura își adapă zeul" ["Vestido de folhas murchas Pan encontra-se sobre um rochedo. / Ele está cego e velho. / Suas pálpebras estáo enrijecidas, / ele tenta em vão piscar, / seus olhos como os caracóis se fecharam no inverno. // Gotas de orvalho quente caem em seus lábios: / uma, / duas, / três. / A natureza alimenta seu deus"] ("Pan"). Cada vez mais consciente das lacunas entre si e do mundo, os sinais e seus significados, os poemas do período médio de Blaga enfatizam a ruptura e a descontinuidade em lugar da unidade do pensamento. Eles começam, segundo Marin Mincu, um lento processo de "des-retorização e desregulação do Expressionismo", * enquanto que os primeiros poemas celebram a expressão individual, o vitalismo cósmico e o movimento. O clamor expres-
* (AUGUSTIN DOINAS, Stefan. Silence and Words. Romanian Review, n. 4, 1970: 82.)

* (MINCU, Marin. Introducere in poezia lui Lucian Blaga. In: Marin Minuc, ed., Lucian Blaga, Poezii. Texte commentate, Bucuresti, Albatros, 1983: xxxvii.) 
sionista em "Eu quero dançar!” / "Vreau să joc!” “"O, vreau să joc, cum niciodată n-am jucat / Să nu se simtă Dumnezeu / în mine / un rob în temniţă - incătuşat?" ["Oh, eu quero dançar, como nunca dancei! / Que Deus não se sinta / em mim / um escravo acorrentado em uma prisão!"]) reaparece em um poema do volume $O s$ passos do profeta ("Dai-me um corpo, oh montanhas" / "Daţi-mi un trup, voi munţilor"): "Dați-mi un trup, / voi munţilor, / mărilor, I dați-mi alt trup să-mi descarc nebunia I in plin?" ["Dai-me um corpo, / oh montanhas, / mares, / dai-me outro corpo para descarregar minha loucura / por inteira!"].

Revivido pelos existencialistas algumas décadas atrás ( $O$ mito de Sisifo data de 1942), o absurdo lhes aparece como a recusa da existência em conformidade com razōes humanas. Confrontado com paredes absurdas, obstáculos que Blaga também leva em consideração, a resposta no plano da consciência, proposta por Camus, é uma revolta, uma revolta criativa única que pode atenuar o sentimento de amargura. Para Blaga, a neutralização completa da ansiedade não é possível, mas ele encontra, no entanto, várias soluçóes para apaziguá-la: uma delas é o eros tal como visto no Poemas da luz, um método de esquecer, como alguns críticos consideraram: "Atâtea stele cad în noaptea asta. I Demonul nopţii ţine parcă-n mâini pământul / și suflă peste el scântei ca peste-o iască I năpraznic să-l aprindă. I În noaptea asta-n care cad I atâtea stele, tânărul tăn trup / de vrăjitoare-mi arde-n brațe / ca-n flăcările unui rug" ["Tantas estrelas caem nesta noite. / O demônio da noite como que tem nas mãos a terra / e sopra sobre ela faíscas como sobre gravetos / para bruscamente acendê-los. / Nesta noite, em que caem / muitas estrelas, seu corpo jovem / de feiticeira arde em meus braços / como nas chamas de uma fogueira”] ("Noi și pământul" / "Nós e a terra"). Outra é ficar livre de tudo ao seu redor e se aproximar do estado primal dos simples animais: "Dă-mi mâna ta trecătorule, şi tu care mergi, I și tu care vii. I Toate turmele pământului au aureole sfinte / peste capetele lor. I Astfel mă iubesc de-acum: / unul între mulţi” ["Dá-me tua mão, transeunte, sejas aquele que vai, / sejas aquele que chega. / Todos os rebanhos desta terra têm auréolas santas / sobre suas cabeças. / Assim me amo agora: / um entre muitos"] ("Am înţeles păcatul ce apasă peste casa mea" / "Compreendi o pecado que pesa sobre minha casa”).

Há muito tempo notou-se que os gregos não transpuseram a realidade em arte, eles apenas a introduziram por intermédio da 
ficção em mitos. O paradoxo de Blaga, um espírito consumido pelo desejo de certeza, é o seu envolvimento paralelo na imprecisão do mistério, em uma zona nebulosa do subconsciente; a palavra já não denota precisamente, como em "O pássaro santo. Moldado em ouro pelo escultor Constantin Brâncuși” / "Pasărea sfântă. Întruchipată în aur de sculptorul Constantin Brâncuși”": "Pasăre ești? Sau un clopot prin lume purtat? / Făptură ți-am zice, potir fără toarte, I cântec de aur rotind / peste spaima noastră de enigma moarte. // Fosfor cojit de pe vechi oseminte / ne pare lumina din ochii tăi verzi" ["Será um pássaro? Ou um sino a ser levado pelo mundo? / Uma criatura, jarro sem alças. / Canção de ouro rodando / sobre nosso medo do enigma da morte. // O brilho de teus olhos verdes parece / fósforo de velhos ossos despelados"]. Daí o dualismo entre o eu e o mundo. Além disso, a sensação de desintegração é, por vezes, extremamente poderosa, como em "Paisagem transcendente" / "Peisaj transcendent": "Cocoși apocaliptici tot strigă, / tot strigă prin sate românești. / Fântânile nopții / deschid ochii și-ascultă / întunecatele vești" ["Galos apocalípticos gritam todos, / gritam todos pelas aldeias romenas. / As fontes das noites / abrem os olhos e escutam / as trevosas notícias"].

Se a essência do ser humano consiste em "definir o mistério e tentar revelá-lo”, como Blaga coloca, então a poesia verdadeira é aquela que os conecta a duas modalidades adequadas ao pensamento humano: o pensamento mítico e o mágico. O primeiro se esforça "para revelar um mistério com os meios de imaginação", enquanto que no segundo "o próprio mistério como tal adquire consistência como em um apêndice lúcido de si próprio”. Portanto, Ştefan Augustin Doinaş concluiu que a poesia genuína deve ter um certo "conteúdo" mítico e mágico para os vários níveis do material verbal no qual está incorporado. Daí o amplo debate crítico sobre a relaçáo entre a teoria do mistério e a imagem daquele específico "Grande Anônimo" ou mesmo do "anonimato", muitas vezes presente em sua obra. Blaga tentou esclarecer tudo afirmando que "Anônimo não significa coletivo. $\mathrm{O}$ coletivo é uma soma de indivíduos. $\mathrm{O}$ anônimo, entretanto, é a soma de tudo. Nisto penso que difiro do Expressionismo alemão - o qual é alternadamente coletivista e individualista”. O próprio poeta admitiu que, com o tempo, o seu Expressionismo, especialmente com Em louvor ao sono, "tomou uma forma bem organizada e cristalina que mereceu o rótulo de neoclássico". Por isso, podemos dizer que os poemas 
* (PAZ, op. cit.: 35.$)$

* (CORNIS-POP, op. cit.: 193.)

* (CODRESCU, op. cit.: xviii.) da maturidade de Blaga buscam confirmação, e não novos começos, retrabalhando temas anteriores e cultivando algumas técnicas aprendidas com o folclore romeno: "Frate, o boală invinsă ţi se pare orice carte. / Dar cel ce ți-a vorbit e în pământ. / E în apă. E în vânt. / Sau mai departe. // Cu foaia aceasta inchid porţile și trag cheile. I Sunt undeva jos au undeva sus. I Tu stinge-ți lumânarea și-ntreabă-te; / taina trăită unde s-a dus?" ["Irmão, qualquer livro te parece uma doença vencida. / Mas aquele que te falou está na terra. / Está na água. Está no vento. / Ou mesmo mais longe. // Com esta página fecho a porta e guardo a chave. / Estou em algum lugar abaixo ou em algum lugar acima. / Apaga tua vela e pergunta-te; / para onde foi o mistério vivo?"] ("Încheiere" / "Fim"). Mas "a nostalgia moderna por um tempo original e pela humanidade reconciliada com a natureza é uma atitude radicalmente diferente de concepçôes pré-cristãs. Contudo, tal como o mundo pagão, que postula a existência de uma idade de ouro antes da história, essa idade não se encaixa em uma visão cíclica do tempo".* E isso acaba por ser verdade no caso da poesia de Blaga: suas imagens, "mesmo quando toma emprestado de uma base tradicional, mítico-pastoral, são dissonantes e distorcidas", ${ }^{*}$ como enfatiza Marcel Cornis-Pop. Aqui estâo alguns exemplos: "Intrat-a o boală în lume, / fără obraz, fără nume. // Făptură e? Sau numai vânt e? / $N$-are nimenea grai s-o descânte. / Bolnav e omul, bolnavă piatra, / se stinge pomul, se sfarmă vatra." ["Uma doença entrou no mundo, / sem nome, sem rosto. // É criatura? Ou é apenas vento? / Nenhuma voz pode domá-la. / O homem está doente, doente a pedra, / definha a árvore, quebra o fogareiro"] ("Boală" / "Doença"); ou: "Pe creasta nopții moara seacă / macină lumină-n gol. / Lopeţi se-nalţă și s-apleacă. // Războiul după ușă pus / ţese singur - vezi suveic? / Fă o cruce spre apus" ["No alto da noite o moinho seco / mói a luz vazia. / Suas pás dançam para cima e para baixo. // O tear atrás da porta / tece por si só vês algum fuso? / Faze o sinal da cruz para o oeste"] ("Vraja şi blestem" / "Magia e maldição").

Alguns dos mitos de Blaga incluídos em sua poesia são propositadamente "ingenuamente medievais, como os afrescos nas paredes de um mosteiro bizantino", ${ }^{*}$ tal como Andrei Codrescu colocou: São Jorge vagando, velho, em busca dos dragóes que todas as moças nas aldeias amam. Outros são vagamente gregos, encenados desajeitadamente em rochas pintadas e cavernas de papelăo: Pan envelhece com uma aranha como seu único amigo. Outras histó- 
rias são textualmente folclóricas: "Doarme colo în poiană / pruncușor fără de tată. / Și măicuţa mama lui / se tot plânge boului / c-a născut in Vifleim / n-are scutece de in, / n-are apă, n-are faşă, / nici opaiț, nici nănașă. // Iosif cercul de pe cap / în cuier și l-a lăsat / și-a plecat unde-a plecat / ca să-l latre câinii-n sat" ["Dorme no prado / a criança sem pai. / Sua mãe chora / se queixa ao boi / que havia nascido em Belém / que não tem roupa, / nem água, nem bandagem, / nem candeeiro, nem ama. / José pendurou seu gorro / em um prego na porta / e saiu para algum lugar / ao latido de cáes de estranhos"] ("Colindă" / "Cantiga de Natal"). "O encanto dos mitos não está em sua natureza religiosa, mas no fato de que neles a narrativa poética transfigura o mundo e a realidade".*

O transcendental interessa Blaga precisamente como ficção mítica (emblemática): os poemas do período mediano abundam em referências ao mito e seus correlatos (história, lenda, conto de fadas que poderiam ser chamados de ancestrais). Blaga respondeu à angústia moderna da "grande travessia" reafirmando o valor da narração mítica: "Se odihnește subt prunii bisericii, adulmecă / arhaicul vânt. O fată $i$-a pus ieri în braţe un crin. / Va mai trece printr-o mie de sate. / I se va-ntinde prescură, pe drumuri stropite cu vin" ["Ele está descansando sob as ameixas da abadia, respirando / o vento antigo. Ontem uma moça deu-lhe um lírio. / Ele passará por milhares de aldeias. / Lhe será oferecido o pão sagrado, em estradas com vinho espargidas"] ("Ursul cu crin" / "O urso com o lírio"). A aldeia, no entanto, é um espaço idealizado da mente, um lugar imaginado, às vezes se assemelhando a um "paraíso em derrocada", sendo este também o título de um famoso poema de Blaga: "Portarul înaripat mai ține întins / un cotor de spadă fără de flăcări. / Nu se luptă cu nimeni, / dar se simte învins. // [...] Noaptea îngerii goi / zgribulind se culcă în fân / vai mie, vai ție, / păianjeni mulți au umplut apa vie, / odată vor putrezi și îngerii sub glie, I ţărâna va seca poveștile / din trupul trist" ["O porteiro alado empunha ainda / um resto da espada sem chamas. / Não luta com ninguém, / mas se sente derrotado. // (...) À noite, anjos nus / amontoam-se tremendo no feno: / ai de mim, ai de ti, / a água da vida está cheia de aranhas, / mesmo os anjos vão apodrecer um dia sob a sujeira, / a poeira irá secar as histórias / do triste corpo"].

Os românticos cultivaram a terapia do sono, Hölderlin, Novalis e Eminescu preferiram o estado de sonho a caminhar. Para Blaga, o sono é muitas vezes atormentado e povoado por estranhas figuras 
míticas, como em "Cidade velha" / "Oras vechi": "Noapte. Urnirea orelor / se-mplinește färă îndemn. / Taci, - arătătoare se-opresc / suspinând pe ultimul semn" ["Noite. As horas passam / perfazendose sem pressa. / Silenciou, - os ponteiros param / suspirando no último sinal"]. As imagens estão de alguma forma lembrando o leitor da obra lírica de Georg Trakl. No entanto, o tratamento dos mitos aproxima Blaga de Yeats, um dos poetas que ele mesmo traduziu. "Busquei uma linguagem simbólica que atravessasse as fronteiras do passado, estando associada a denotaçóes familiares e ideias amplamente conhecidas", Yeats escreveu em seus Ensaios. Sobre a acusação de que sua poesia é "mítica e metafísica", Blaga admite não apenas temas míticos, mas também teológicos: livre, embora, tal como Yeats, do rigor do dogma. Blaga está preocupado principalmente com uma estilização analógica pessoal, na medida em que um escritor moderno pode revitalizar as funções da metáfora simbólica. Ele, portanto, inventa no espírito, não na letra de seus modelos populares.* "Meus temas não são tratados dogmaticamente. Sempre os utilizo de forma criativa: modificando-os e ampliando-os livremente se for necessário. Apresento temas míticos a cada passo, porque sem um pensamento mítico, felizmente ou não, nenhum poema pode vir a ser", disse Blaga. A visão mítica consiste entấo essencialmente em transfiguração, reencarnação progressiva.

$\mathrm{O}$ muito antigo pode ser adotado pela modernidade se se rejeita a tradiçâao do momento e se propóe uma diferente. Consagrado pelas mesmas forças polêmicas que o novo, o que é muito antigo não é um passado, mas um começo. Nossa paixáo por contradiçóes o ressuscita, dando-lhe vida e tornando-o nosso contemporâneo. A arte e a literatura modernas consistem da descoberta contínua do muito antigo e distante, da poesia popular germânica descoberta por Herder à poesia chinesa recriada por Pound. [...] Como manifestaçôes da estética da surpresa, mas ainda mais como encarnaçôes momentâneas de negaçáo crítica, os produtos da arte arcaica e de civilizaçóes distantes se encaixam naturalmente na tradiçáo de descontinuidade. Eles estáo entre as máscaras da modernidade.*

No mundo poético de Blaga a fertilidade mítica dos primórdios deixou uma atmosfera na qual o poeta fez sua casa. Se Blaga deve ser comparado com alguém,

deveria ser com Rilke, a quem dedica um poema comovente. O Expressionismo, com suas ramificaçóes vitalistas e avant-garde, foi o pano de fundo para esses dois poetas cujas sensibilidades tinham um grande desejo de desaparecer no mítico inconsciente coletivo. 
Ambos sentiram sua condição como um exílio, mas o de Rilke era de fato um exílio, o exílio de Blaga consistiu em uma saudade aguda pela próprio lugar onde estava. Este lugar, além disso, mantém a marca do mito em sua casca vazia. O poeta encontra os " profeta" em toda parte.*

No entanto, começando com Em louvor ao sono, Blaga utilizou técnicas expressionistas muito vagamente, subordinando-as a uma mitopoiesis original, uma redefinição simbólica de realidades espirituais romenas. Tal como o seu compatriota Mircea Eliade, Blaga perseguiu uma síntese pessoal entre a herança racionalista do Ocidente e o potencial mágico-mítico inexplorado do Oriente. $\mathrm{O}$ mito para ele era uma ferramenta importante para relacionar duas grandes tradiçôes culturais. Portanto, Blaga gostou de associar seus poemas mais tarde com a "espontaneidade herética do gênio popular". Pode-se encontrar este espírito tão cedo quanto em poemas como "Segurando a mão do grande homem cego", "O caminho do santo", " Cantiga de Natal " ou "Boas novas pela florescência da macieira”, poemas que reativam o potencial metafórico dos mitos bíblicos. "Mas os poemas são marcados pelo drama da separação ontológica e cognitiva, o eu que retratam é distante do horizonte original do mistério".*

Para todos os fundadores, a poesia é o mundo em tempo não sequencial, o tempo do corpo e do desejo. "Palavra iniciadora: palavra fundadora. Mas também palavra desintegradora, a romper com a analogia por meio da ironia ou da angústia, por meio da consciência da história que neles é o conhecimento da morte".* Lucian Blaga parece subscrever esta opiniāo e incorporá-la ao longo de todo o seu trabalho, colocado, como é, sob o signo duplamente-centrado de tradição e modernidade, uma tradição que muitas vezes revelase extremamente moderna e um certo tipo de modernidade que mantém sempre seu encanto tradicional.

Tradução do inglês por Edmir Missio (Doutor em Teoria Literária / UNICAMP)
* (CORNIS-POP, op. cit.: 195.)

* (PAZ, op. cit.: 57.)

Rodica Grigore é professora sênior com Ph.D. em Literatura Comparada na Universidade Lucian Blaga de Sibiu, Romênia. Escreveu cinco estudos críticos: Despre cărţi şi alţi demoni [De livros e outros demônios, 2002], Retorica măştilor în proza interbelică românească [A retórica das máscaras na ficção moderna romena, 2005], Lecturi in labirint [Leituras no labi- 
rinto, 2007], Măşti, caligrafie, literatură [Máscaras, caligrafia, literatura, 2011] and In oglinda literaturii [No espelho da literatura, 2011]. Também traduziu para o romeno os ensaios de Octavio Paz, Copiii mlaştinii [Os filhos do lodo, 2003], os poemas do escritor colombiano Manuel Cortés Castańeda, Oglinda celuilalt [O espelho do outro, 2006] e uma coleçáo de novelas e contos do escritor americano Andrei Codrescu, Un bar din Brooklyn [Um bar no Brooklyn, 2006]. Desde 2005, Rodica coordena a antologia do International Theatre Festival of Sibiu. Publicou numerosos ensaios e estudos críticos especialmente sobre literatura moderna em várias revistas literárias romenas: Cultura, Observator Cultural, Contemporanul, Euphorion, Transilvania, Scrisul Românesc, Viaţa Românească etc. Também é conhecida como tradutora de inglês, francês e espanhol, e recentemente foi autora de uma breve antologia da poesia romena publicada no México, Espanha, Peru, Venezuela e Argentina. 